\title{
Surfaces
}

Marchetti, Gina. Romance and The "Yellow Peril": Race, Sex and Discursive Strategies in Hollywood Fiction. Berkeley: University of California Press, 1994. 258 pp., cloth and paper

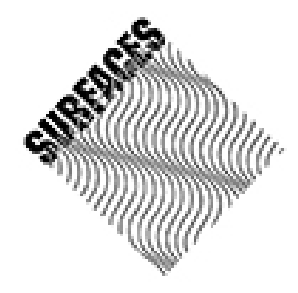

\section{Karen Nicholson}

Volume 5, 1995

URI : https://id.erudit.org/iderudit/1065005ar

DOI : https://doi.org/10.7202/1065005ar

Aller au sommaire du numéro

Éditeur(s)

Les Presses de l’Université de Montréal

ISSN

1188-2492 (imprimé)

1200-5320 (numérique)

Découvrir la revue

Citer ce compte rendu

Nicholson, K. (1995). Compte rendu de [Marchetti, Gina. Romance and The

"Yellow Peril": Race, Sex and Discursive Strategies in Hollywood Fiction.

Berkeley: University of California Press, 1994. 258 pp., cloth and paper].

Surfaces, 5. https://doi.org/10.7202/1065005ar 


\section{Book Review}

\section{Gina Marchetti : Romance and the "Yellow Peril"}

Karen Nicholson

Université de Montréal

Département de littérature comparée

Surfaces Vol.V.01 (v.1.0A - 15/09/1995)

Copyright for texts published in SURFACES remains the property of authors. However, any further publication should be accompanied by an acknowledgement of SURFACES as the place of initial publication.

ISSN: $1188-2492$

\section{Marchetti, Gina. Romance and The "Yellow Peril": Race, Sex and Discursive Strategies in Hollywood Fiction. Berkeley: University of California Press, 1994. 258 pp., cloth and paper.}

Romance and The "Yellow Peril": Race, Sex and Discursive Strategies in Hollywood Fiction constitutes the first substantial study of the treatment of Asian-Caucasian romantic and sexual relations in American popular cinema. Adopting a feminist perspective, Gina Marchetti examines and deconstructs the manner in which Hollywood narratives of interracial romance maintain, and occasionally subvert, culturally accepted notions of nation, class, race, ethnicity, gender and sexual orientation. The corpus of this study, composed of 17 mainstream films dating from 1958 to 1986, and pertaining to Japan, China and Vietnam, exemplifies specific "narrative formulas" common to the Hollywood interracial romance, each of which addresses, and ultimately resolves various racial and sexual tensions within the American social and cultural consciousness. It is Marchetti's contention that, taken as a whole and situated within their particular epistemological frameworks, these "narrative formulas" underline certain contradictions that exist within American identity in its attitudes toward race, gender, sexuality and class.

Drawing on narrative analysis by Fredric Jameson and Antonio Gramsci, Marchetti regards Hollywood realist film as a form of discourse, as an 
ideologically constructed object of signification that functions within a larger epistemological framework. In order to view the portrayal of race and sexuality in American mainstream film as representative of popular norms and attitudes, it is then necessary to examine the socio-historical, political and cultural climate of which each particular film is part and product. Marchetti contends that Hollywood's longstanding interest in the theme of interracial relations, regardless of the prohibition of miscegenation narratives by The Motion Picture Association of America, underscores profound ideological tensions between "melting pot" liberalism and the conservative definition of American identity as white Anglo-Saxon. Despite the fact that Hollywood realist film, the romance in particular, operates a form of structuralist essentialism that æstheticizes and symbolically resolves social contradictions while effectively masking their white Anglo-Saxon male ideological grounding, a deconstruction of the depiction of race, gender, sexuality and class within these narratives exposes rifts within American society at large. The ideological machinations of this narrative process are not openly disclosed to the viewer; instead, questions of racial, cultural and sexual difference are glossed over in the promised glow of heterosexual romance.

Marchetti contends that at the core of these realist narratives lies the JudeoChristian mythical tradition that is deeply-seated both in Western culture and in the foundation of American identity: interracial rape, captivity, seduction, salvation, sacrifice, assimilation, tragic, as well as transcendent love, at the root of Hollywood's portrayal of Asian-Caucasian relations, also represent veritable leitmotivs of American popular fiction. It is suggested that, in fact, these themes are common to narratives regarding African Americans, Native Americans, Mexicans and Asians. All of these "narrative formulas" suppose a racial threat to the sanctity of American identity and moral purity; in the case of the films analyzed here, the Asian character embodies the menace of the "Yellow Peril," an inherently ambivalent fantasy "that projects Euroamerican desires and dreads onto the alien other"(2). This popular belief in the racial and cultural inferiority of members of the Asian race, in their need of Anglo-Saxon Christian guidance and salvation, serves as a justification for Occidental imperialist expansion into Asia; in the case of Hollywood cinema, the threat of miscegenation provides the necessary rationalization for the portrayal of Western domination of the racial other. The portrayal of Asia is not the sole, nor even the main focus of the monograph, however; Marchetti examines a spectrum of race, gender, class and sexuality in an attempt to illustrate how all of these narratives address the question of American identity in its relation to the racial other. In sum, on the most superficial level, Hollywood portrayals of interracial romance have met with commercial success because their narrative "flirtation" with sexual transgression and eroticism is resolved without "scandal." Marchetti concludes that, on a more profound level, these narratives pro- vide Hollywood with the possibility to explore and even to define Anglo-American cultural conceptions of race, sexuality, gender and class; yet while the analyses of the roles assigned to women and to Asians within American film and society are the real strengths of the book, within such a wide range of focus, the reader occasionally loses the thread of Marchetti's argument. 
The distinction between theme, leitmotiv and (popular) myth in Marchetti's analysis remains altogether vague; while she adopts a structural perspective and makes specific reference to Lévi-Strauss's and Jameson's analysis of myth as narrative, she does not provide examples of the specific JudeoChristian myths that inform the American interracial tradition. Eight "narrative formulas" are discussed as examples of Hollywood's treatment of Asian-Caucasian romance; it is not clear whether or not others exist as well, nor whether these eight are congruent with or different from those depicting other races and cultures. Marchetti states, in the conclusion, that the narratives discussed in this study are "fundamentally narratives of salvation" (218) in which "racial difference becomes sexual excess, and romantic love acts as both personal salvation and social corrective"(219). In effect, it is heterosexual love that symbolically resolves, within the narrative as microcosm, ideological contradictions present in society. It would seem that the narrative formulæ examined represent variations upon common themes, as the chapter titles would seem to indicate: "Rape Fantasy: The Cheat and Broken Blossoms"; "The Threat of Captivity: The Bitter Tea of General Yen and Shanghai Express" and "Tragic and Transcendent Love: Sayonara and The Crimson Kimono." The organization of the analysis along thematic lines follows a more or less linear chronology, indicating that each theme is representative of a particular epistemological framework. On the other hand, contrary to this thematic grouping, and as Marchetti herself underlines, "any act of domination brings with it opposition, guilt, repression, and resistance"(6). An ideological counter-current "must also be incorporated into these myths and silenced, rationalized, domesticated, or otherwise eliminated. Individual texts become part of a broader narrative pattern that, in each incarnation, reproduces and reworks the same ideological pattern"(6-7). While Marchetti effectively unravels the threads of this resistance within the narratives themselves, in presenting her analysis according to this "broader thematic pattern," is she guilty of operating the same structuralist reductionism, of effectively reproducing the same ideological whitewash as the Hollywood narratives themselves? Although she specifies that narratives pertaining to China, Japan and Vietnam, the three nations most portrayed in Hollywood fiction, will be the focus of her analysis, she does not specify the criteria behind her choice of films, except to say that they do not fall into one particular genre, and, whereas some have been the subject of much critical interest, others have been largely neglected. In fact, these films do not all belong to the same medium, as made-for-television movies are discussed alongside feature-length cinema. What critical measure was employed in their selection? Were these seventeen films selected as being the most representative of the treatment of interracial romance, specifically of Asian-Caucasian interracial romance in American popular tradition, or because they are characteristic of a particular épistémè, or both? Are these the only films that deal with this particular subject matter? While the study seeks to determine how film and television have shaped popular conceptions of Asia, one wonders how its corpus will determine the reader's understanding of the construction of interracial sex and romance in the Hollywood narrative. If the movies in question were chosen because the themes they present allow us to comprehend ideological tensions within society at large, specific crosscultural references would better illustrate this; for example, an analysis of the similarities between the treatment of Pocohantas and Madame Butterfly 
stresses the shared ambivalence associated with these figures in American consciousness. It also underlines a common theme and narrative structure, encouraging us to consider them as mythical avatars: "The myth endures and continues to function not only as a romantic justification for traditional female roles but also as a political legitimation of American hegemony internationally"(108). Unfortunately, examples of this type of cross-cultural analysis are too few in number in Marchetti's work.

In a final discussion of Michael Cimino's The Year of the Dragon as postmodern pastiche, Marchetti makes reference to Lyotard's theory of the legitimation of knowledge through reference to metanarratives. Although the narrative formulas at issue do not constitute metanarratives as such, like them, they are being put into question because of an awareness of the flaws in their ideological foundations. However, discursive strategies in the Hollywood interracial romance are legitimated with reference to an ideologically institutionalized discourse on heterosexual love, namely, redemption through heterosexual romance with a white Anglo-Saxon American; consequently, it becomes possible to consider this discourse as a form of metanarrative, a "masternarrative that links personal salvation and romantic love with social emancipation and progress"(219). As the postmodern spectacle and semantic pluralism of Year of the Dragon confirms, questioning of Hollywood's treatment of Asia and its spiritual and moral glorification of heterosexual romance belies a new crisis in a persisting ideological dilemma:

... these films seem to tell one story about American identity as both superficially liberal and deeply conservative with respect to racial and ethnic differences. All place limits on both the progressive elements in their discourses... as well as their racist aspects that insist on either absolute exclusionism or the subordination of the non-white partner to the Anglo-American. (219)

Marchetii's critique of the textual inscription of gender roles assigned to women and of the "Yellow Peril" discourse is both interesting and revealing; in fact, the very strength of the structural analysis occasionally occludes epistemological inquiry; moreover, the choice of corpus needs further justification. However, Romance and the "Yellow Peril" has the merits of being innovative not only in its examination of the portrayal of Asia in the mainstream American film industry, but also as a work that falls outside the dominant paradigm of feminist film criticism in adopting theoretical perspectives on race and gender by the likes of Gayatri Spivak, bell hooks and Trinh T. Minh-ha. As a result, it will be of general interest to scholars in Asian, film, women's and cultural studies. 